\title{
Two-body wear of monolithic, veneered and glazed zirconia and their corresponding enamel antagonists
}

\author{
Stawarczyk, Bogna ; Özcan, Mutlu ; Schmutz, Felix ; Trottmann, Albert ; Roos, Malgorzata ; Hämmerle,
} Christoph H F

\begin{abstract}
Abstract Objective. This study tested whether the two-body wear of monolithic zirconia and their corresponding enamel antagonists was higher compared to monolithic alloy and veneered zirconia. Materials and methods. Cylindrical specimens $(\mathrm{N}=36, \mathrm{n}=6)$ were prepared out of $(A)$ veneered zirconia $(\mathrm{VZ})$, (B) glazed zirconia using a glaze ceramic (GZC), (C) glazed zirconia using a glaze spray (GZS), (D) manually polished monolithic zirconia (MAZ), (E) mechanically polished monolithic zirconia (MEZ) and (F) monolithic base alloy (control group, MA). Wear tests were performed in a chewing simulator $\left(49 \mathrm{~N}, 1.7 \mathrm{~Hz}, 5^{\circ} \mathrm{C} / 50^{\circ} \mathrm{C}\right)$ with enamel antagonists. The wear analysis was performed using a 3D profilometer before and after 120,000, 240,000, 640,000 and 1,200,000 masticatory cycles. SEM images were used for evaluating wear qualitatively. The longitudinal results were analysed using linear mixed models $(\alpha=0.05)$. Results. Materials $(p<0.001)$ and number of masticatory cycles $(\mathrm{p}<0.001)$ had a significant effect on the wear level. The least enamel antagonist wear was observed for MAZ and MEZ $(27.3 \pm 15.2,28 \pm 11.1 \mu \mathrm{m}$, respectively). GZC $(118 \pm 30.9 \mu \mathrm{m})$ showed the highest wear of enamel antagonists. The highest wear rate in the material was observed in GZS $(91.3 \pm 38.6 \mu \mathrm{m})$. While in the groups of MA, VZ, GZC and GZS 50\% of the specimens developed cracks in enamel, it was $100 \%$ in MAZ and MEZ groups. Conclusion. Polished monolithic zirconia showed lower wear rate on enamel antagonists as well as within the material itself but developed higher rates of enamel cracks.
\end{abstract}

DOI: https://doi.org/10.3109/00016357.2011.654248

Posted at the Zurich Open Repository and Archive, University of Zurich

ZORA URL: https://doi.org/10.5167/uzh-62923

Journal Article

Accepted Version

Originally published at:

Stawarczyk, Bogna; Özcan, Mutlu; Schmutz, Felix; Trottmann, Albert; Roos, Malgorzata; Hämmerle, Christoph H F (2013). Two-body wear of monolithic, veneered and glazed zirconia and their corresponding enamel antagonists. Acta Odontologica Scandinavica, 71(1):102-112.

DOI: https://doi.org/10.3109/00016357.2011.654248 
Journal: Acta Odontol Scand

Original Article

\section{Two-body wear of monolithic, veneered and glazed zirconia and their corresponding enamel antagonists}

Short title: Wear of zirconia ceramics and human enamel

Bogna Stawarczyk, Mutlu Özcan, Felix Schmutz, Albert Trottmann, Malgorzata Roos, Christoph H.F. Hämmerle

\section{Abstract}

Objective. This study tested whether the two-body wear of monolithic zirconia and their corresponding enamel antagonists was higher compared to monolithic alloy and veneered zirconia. Material and methods. Cylindrical specimens $(\mathrm{N}=36, \mathrm{n}=6)$ were prepared out of $\mathrm{A})$ veneered zirconia (VZ), B) glazed zirconia using a glaze ceramic (GZC), C) glazed zirconia using a glaze spray (GZS), D) manually polished monolithic zirconia (MAZ), E) mechanically polished monolithic zirconia (MEZ) and F) monolithic base alloy (control group, MA). Wear tests were performed in a chewing simulator $\left(49 \mathrm{~N}, 1.7 \mathrm{~Hz}, 5^{\circ} \mathrm{C} / 50^{\circ} \mathrm{C}\right)$ with enamel antagonists. The wear analysis was performed using a 3D profilometer before and after $120.000,240.000,640.000$, and 1.200.000 masticatory cycles. SEM images were used for evaluating wear qualitatively. The longitudinal results were analysed using linear mixed models $(\alpha=0.05)$. Results. Materials $(p<0.001)$ and number of masticatory cycles $(p<0.001)$ had a significant effect on the wear level. The least enamel antagonist wear was observed for MAZ and MEZ $(27.3 \pm 15.2,28 \pm 11.1 \mu \mathrm{m}$, respectively). GZC $(118 \pm 30.9 \mu \mathrm{m})$ showed the highest wear of enamel antagonists. The highest wear rate in the material was observed in GZS $(91.3 \pm 38.6 \mu \mathrm{m})$. While in the groups of MA, VZ, GZC and GZS $50 \%$ of the specimens 
developed cracks in enamel, it was $100 \%$ in MAZ and MEZ groups. Conclusion. Polished monolithic zirconia showed lower wear rate on enamel antagonist as well as within the material itself but developed higher rates of enamel cracks.

Key Words: monolithic zirconia, ceramic, abrasion, enamel, two-body wear 


\section{Introduction}

Physical, mechanical and chemical properties make zirconia a material of interest for dental reconstructions [1-4]. Zirconia exhibits polymorphic properties meaning that same chemical composition exists in its different atomic arrangements [5,6]. Among the crystallographic structures, the monoclinic phase is stable up to $1170^{\circ} \mathrm{C}$ which then transforms into the tetragonal phase $[5,6]$. The tetragonal form for metastable zirconia in biomedical applications could be achieved at room temperature by alloying zirconia with other oxides (stabilizers) [710]. $\mathrm{Y}_{2} \mathrm{O}_{3}(3 \% \mathrm{~mol})$ is the most widely used stabilizer for dental zirconia [6].

Limited number of clinical studies reported seldom zirconia framework fractures but more often chipping of the veneering ceramic [11-15]. In order to decrease the costs and at the same time overcome the chipping problem, it is possible today to produce zirconia fixed dental prosthesis (FDPs) without veneering ceramic, called monolithic zirconia reconstructions. Currently, monolithic zirconia reconstructions could be constructed and subsequently only polished or characterized using a glaze layer in different colours. Glaze layer could be applied using layering technique or a glaze spray.

To the authors' best knowledge at present there is no information on the clinical performance of the available newly introduced monolithic zirconia reconstructions. Particularly mechanical properties, such as hardness, wear resistance, or fracture toughness, are supposed to influence the wear performance of such zirconia ceramics strongly [ 16-18]. In that respect, zirconia is expected to demonstrate favourable properties.

One in vitro study tested the wear of five zirconia materials versus steatite and human enamel antagonist and found no wear in the zirconia ceramic. In that study, the wear rate of the enamel antagonists were not determined, but it was stated that the enamel generally showed cracks or even fractures at the ridges, in all tested zirconia ceramics [18]. 
Wear presents the loss of material from a surface, caused by mechanical contact, against a solid or liquid body, chemical reactions or simultaneous effect of chemical and mechanical reactions [19]. The hardness and thickness of enamel [18,20], the chewing behaviour in combination with parafunctional habits and neuromuscular forces $[18,21,22,23]$, as well as the abrasive nature of food and the antagonist material all influence the clinical wear. Zirconia has elasticity modulus of $210 \mathrm{GPa}$ and hardness of $1200 \mathrm{HV}$ [1]. On the other hand, since veneering glass ceramic has elasticity modulus of 50-70 GPa and Vickers hardness of 470-600, more wear could be expected in enamel against non-veneered monolithic zirconia.

Wear test have been performed in the dental literature using the test methods such as Acta, Zurich, Alabama, Freiburg, Minnesota, OHSU or Newcastle [19]. These test methods differ in the antagonist material and design, test medium, force application and mobility of specimens [19]. Among all these test methods, Zurich wear test method uses human enamel antagonists making the test more clinically relevant.

The aim of this study was to investigate the two-body wear characteristics of differently polished monolithic, glazed and veneered zirconia and the wear of their corresponding enamel antagonists. The tested hypotheses were that a) polished monolithic zirconia would show higher wear of enamel antagonist compared to all other tested groups and b) polished monolithic zirconia would show similar abrasion resistance compared to veneered zirconia and monolithic alloy.

\section{Material and Methods}

This study tested the two-body wear of veneered zirconia (VZ), glazed zirconia using a glaze ceramic (GZC), glazed zirconia using a glaze spray (GZS), manually polished monolithic zirconia (MAZ), mechanically polished monolithic zirconia (MEZ), monolithic base alloy (control group, MA) and their corresponding enamel antagonists using Zurich wear 
simulation (ISO/TS 14569-2) [19]. For each test group 6 specimens were fabricated. Table I describes the tested groups.

\section{Specimen preparation}

For all test groups one zirconia cylinder in white state (ZENOTEC Zr Bridge transluzent, Wieland Dental + Technik, Pforzheim, Germany) (diameter: $18 \mathrm{~mm}$, length: $50 \mathrm{~mm}$ ) and for the control group (MA), one wax cylinder (ZENO TEC Wax Disc, Wieland Dental + Technik) (diameter: $15 \mathrm{~mm}$, length: $50 \mathrm{~mm}$ ), were milled using a milling machine (ZENOTEC T1, Wieland Dental + Technik). Subsequently, the zirconia $(\mathrm{N}=30, \mathrm{n}=6)$ and wax cylinder $(\mathrm{N}=6)$ were cut to a thickness of $2 \mathrm{~mm}$ with a low-speed diamond saw (Well 3241, Well Diamantdrahtsägen, Mannheim, Germany). The round specimens were ground to the final dimensions using SiC discs P600 (Silicon Carbide Paper, Struers, Ballerup, Denmark) under water-cooling.

The zirconia specimens were sintered in the sintering oven (Thermostar, ZENO Fire, Wieland Dental + Technik, final sintering temperature: $1580^{\circ} \mathrm{C}$ and holding time: $4 \mathrm{~h}$ ) according to the manufacturer's instructions.

Thereafter, the surfaces of zirconia $(n=12)$ were air-abraded using $120 \mu \mathrm{m}$ alumina for $10 \mathrm{~s}$ at a pressure of 4.5 bar from a approximate distance of $10 \mathrm{~mm}$ (LEMAT NT4: Wassermann; Hamburg, Germany). The zirconia surfaces were treated as follows using the ceramic firing parameters as described in Table II:

(A)Veneered zirconia (VZ): The zirconia surface was conventionally veneered according to the manufacturer's instructions, where initially a liner was applied (Liner A3 with Liner Liquid Optimix, Wieland Dental + Technik). Then dentin ceramic (Dentin A3, Zirox dentin with Carving Liquid Standard, Wieland Dental+ Technik), enamel ceramic (Enamel A3, Zirox enamel with Carving Liquid Standard, Wieland Dental + Technik) and glaze ceramic (Glaze Zirox with Stain Liquid, Wieland Dental + Technik) were added twice. 
(B) Glazed zirconia using a glaze ceramic (GZC): The zirconia surface was glazed according to the manufacturer's instructions using glaze ceramic (Glaze Zirox with Stain Liquid, Wieland Dental + Technik) twice.

The remaining specimens $(\mathrm{N}=18, \mathrm{n}=6)$ were randomly divided into three groups and treated as follows:

(A)Glazed zirconia using a glaze spray (GZS): The zirconia surfaces were manually polished and glazed according to the manufacturer's instructions using glaze spray (ZENOStar Magic, Wieland Dental + Technik) twice.

(B) Manually polished monolithic zirconia (MAZ): The zirconia surfaces were polished using a goat hair brush (DT \& Shop) and diamond paste (Dia-Glace, Yeti Dental) for $1 \mathrm{~min}$.

(C) Mechanically polished monolithic zirconia (MEZ): The zirconia surfaces in this group were polished up to $3 \mu \mathrm{m}$ using diamond suspensions (Struers, Ballerup, Denmark) in a polishing device (Accutom, Struers).

In the control group, the wax specimens were invested (Wilavest Quick, Wieland Dental + Technik) according to the manufacturer's instructions. After evaporating the wax in a standard oven (EWL Type 5636, KaVo, EWL, Leutkirch am Allgäu, Germany), the alloy (dentaNEM, Wieland Dental + Technik) was casted (Multicast compact, DeguDent, Hanau, Germany). The investment material was removed after cooling in a sandblasting unit (CEMAT NT4, Wassermann, Hamburg, Germany) using $110 \mu \mathrm{m}$ alumina particles (Renfert, Hilzingen, Germany) at 4 bar pressure. Then, the alloy specimens were polished using a goat hair brush (DT \& Shop, Mangelsfeld, Germany) and diamond paste (Dia Glaze, Yeti Dental, Engen, Germany) for 1 min per specimen.

For two-body wear test, all specimens were fixed and embedded in the middle of round stainless steel mold using a chemically cured pattern resin (DuraLay, Dental Mfg, Worth, IL, USA). The specimens were aged in a chewing simulator (custom made: University 
of Zurich), where thermo-mechanical loading was applied during cyclic loading, with maximum occlusal load of $49 \mathrm{~N}$ at $1.7 \mathrm{~Hz}$ and simultaneous thermal stress $\left(5^{\circ} \mathrm{C}\right.$ to $50{ }^{\circ} \mathrm{C}$ every 120 seconds). For simulating a typical clinical situation, mesiobuccal cusp from nearly identical maxillary human molars, fixed in amalgam (Dispersalloy; Dentsply; Konstanz, Germany), acted as antagonists. The tip of the cusps was rounded to a spherical shape. The abraded surfaces were loaded intermittent. The horizontal distance between specimen surface and the enamel antagonist was $2 \mathrm{~mm}$. The profiles of the specimens were measured with a 3D profilometer (custom made: University of Zurich) before aging and after 120.000, 240.000, 640.000, and 1.200.000 masticatory cycles [19]. The vertical material loss $(\mu \mathrm{m})$ of each specimen and the corresponding enamel antagonist was calculated using the 3DS software (custom made: University of Zurich) by overlapping the profiles with congruent points and subtracting the initial measurements from subsequent measurements.

For the qualitative characterisation of wear patterns, all specimens and enamel antagonists were evaluated under scanning electron microscopy (SEM) (Carl Zeiss Supra 50 VP FESEM, Carl Zeiss, Oberkochen, Germany).

\section{Statistics}

The data set were analysed with statistical software (SPSS Version 19, SPSS INC, Chicago, IL, USA). Descriptive statistics were computed. Linear mixed models were applied to investigate the influence of the number of masticatory cycles, reconstruction materials/enamel and the interaction between them. All results with p-values smaller than 5\% were considered as statistically significant.

\section{Results}

The descriptive statistics of the wear results belonging to the reconstruction materials and their corresponding enamel antagonists are summarized in Table III. Reconstruction materials $(p<0.001)$ and number of masticatory cycles $(p<0.001)$ had a significant effect on the wear. 


\section{Material wear}

GZC $(p<0.001)$ and GZS $(p=0.033)$ showed higher wear rate compared to the control group (MA). No statistical differences were observed between the control group (MA) and VZ $(p=0.314), \operatorname{MAZ}(p=0.751)$ and MEZ $(p=0.771)$ (Table IV, Fig. 1$).$

$\mathrm{VZ}(\mathrm{p}<0.001)$ and GZS $(\mathrm{p}<0.001)$ showed significantly higher increase in the material wear itself dependent on the number of masticatory cycles compared to the control group. Between MA, GZC $(p=0.824), \operatorname{MAZ}(p=0.290)$ and MEZ $(p=0.285)$ no differences were found (Table IV, Fig. 1).

\section{Antagonist enamel wear}

GZC $(p<0.001)$ showed higher wear rate of enamel antagonists than the control group, MA. No differences between MA and other tested groups $(\mathrm{p}>0.369)$ were found in wear values of enamel antagonists (Table V, Fig. 2).

GZC ( $p=0.007)$ showed significantly higher increase than MA in loss of enamel antagonist dependent on the number of masticatory cycles. In contrast, the increase of wear of enamel antagonists was lower for MAZ $(p=0.001)$ and MEZ $(p=0.002)$ compared to the control group dependent on aging time. Between MA, VZ $(p=0.193)$ and GZS $(p=0.939)$ no differences were found in terms of enamel wear increase (Table V, Fig. 2).

The qualitative characterisation of wear of all reconstruction materials and their enamel antagonists are summarized in Fig. 3 and Fig. 4.

Evaluation of the enamel antagonists with SEM showed damage in the form of cracks on the worn enamel surface. While in the MA, VZ, GZC and GZS groups $50 \%$ of specimens developed cracks in enamel, it was $100 \%$ in both MAZ and MEZ groups.

\section{Discussion}

This study showed that the wear rate in the material and on enamel antagonists was strongly dependent on the reconstruction material. Polished monolithic zirconia (MAZ, MEZ) showed 
the lowest wear rate on enamel antagonists of all tested groups. Sandblasted and subsequently glazed zirconia using a glaze ceramic, the highest wear on enamel antagonists compared to all other test groups. Therefore, the first hypotheses that polished monolithic zirconia would present higher enamel antagonistic wear is rejected. The highest wear rate was observed for veneered and both glazed zirconia groups. On the other hand, the polished zirconia showed no wear in the material. No differences in zirconia and enamel wear were found between polished zirconia regardless of the polishing method. Hence, the second hypothesis that monolithic zirconia would show similar wear resistance compared to veneered, glazed zirconia and monolithic alloy, is also rejected. One other study tested the wear performance of polished hipped and presintered zirconia using a steatite balls and human enamel as antagonist. Similar to our results, in that study none of the tested zirconia ceramics showed any wear after the simulation tests neither with steatite nor with enamel [18].

Glazing of zirconia may be required for aesthetic improvement of reconstructions. Under clinical conditions, glaze layers have shown to be worn after six months [24], which may require polishing of the zirconia surfaces after glazing. In this study, we tested the wear of two different glazing methods. The first method tested the wear of sandblasted zirconia that was glazed using a layering technique with glaze ceramic. This group showed the highest wear on enamel antagonist with $118 \mu \mathrm{m}$ after 1.2 Mio masticatory cycles. The wear rate for enamel per year has been reported to range between 30 and $40 \mu \mathrm{m}$ [24]. In this study, the glaze layer was observed to abrade already in the first masticatory cycle (120.000). Most probably, the increase in wear rate of the enamel antagonist was due to the continuous loading of rough sandblasted surface. On the other hand, polished zirconia that were glazed using a glaze spray, showed the highest loss of glaze layer but less enamel wear with $62 \mu \mathrm{m}$ after 1.2 Mio masticatory cycles. These results were comparable with the veneered group. The reason for the low wear rate of enamel compared to sandblasted and glazed zirconia could be due to the polished and smooth zirconia surface in the GZS. Since dental materials should ideally 
present wear behaviour similar to that of enamel, the wear of dental materials is usually characterized in relation to that of dental tissues. These considerations imply that restorative materials, such as ceramics, should not damage natural antagonistic teeth $[18,25]$.

In simulation tests, enamel antagonists are required to present clinical conditions. However, morphological and structural differences of enamel complicate standardized wear testing that may cause high variations in the wear data. In this study, the wear results varied highly within each group. This variation could be attributed to the inhomogeneity in the antagonists, namely human tooth tissues may show variations in geometry or thickness of enamel layers, and may become brittle due to storage conditions.

In summary, monolithic zirconia groups showed the lowest wear rate on enamel and in the material itself compared to all other test groups. However, the evaluation of the enamel antagonists with SEM showed damages in the form of cracks on the worn enamel surface. Both monolithic zirconia groups developed $100 \%$ cracks in enamel, while all other tested groups only $50 \%$. Obviously, sliding of the enamel antagonists on hard zirconia surface caused added cracks of the enamel. Future studies should clarify whether this problem is clinical relevant or happened as a possible consequence of dehydration of the dental tissues under vacuum during SEM analysis. Until this is classified, as clinical alternative to monolithic zirconia the monolithic lithium disilicate ceramic can be used. Early clinical reports show predicable results with lithium disilicate ceramics [26-28].

Most wear tests provide only limited or no correlation with the clinical data [29], ever though they allow a comparative evaluation and ranking of different materials under standardized testing conditions. Therefore, testing conditions close to the clinical situations are preferable. A chewing force of $50 \mathrm{~N}$, applied with the frequency of about 1-1.6 Hz, presents the average mastication load $[18,30]$ and is commonly used for oral simulation $[18,31,32]$. In this method, it is expected that permanent thermal cycling with water removes 
wear debris from the specimens surface, but specimens are kept wet during the whole course of the test, and may have caused additional aging of the specimens [33].

Monolithic zirconia FDPs require higher translucency when they are to be used in the anterior region with superior mechanical properties especially. For this reason, many zirconia manufacturers tend to increase the final sintering temperature with the expectation of increasing the translucency. One must consider the fact that the flexural strength and stability of zirconia above the sintering temperature of $1550^{\circ} \mathrm{C}$ decreases [34]. According to the manufacturer's instructions the zirconia material used in this study was sintered at $1580^{\circ} \mathrm{C}$. The grain size of Y-TZP increased with the rise in final sintering temperature may results in grain pull out and thereby, decreased mechanical properties [34]. The increased grain size may yield to crack propagation since applied stress intensity factor may affect the transformation change [35]. When tetragonal zirconia is subjected to tension, it minimizes this perturbation by expanding its dimensions and transforming to monoclinic zirconia, as this expansion decreases the initially applied tensile stress [5]. The phase transformation is combined with the aging effect of zirconia and decreases the mechanical properties [5]. In this study however, none of the monolithic zirconia specimens were broken. The long-term mechanical stability of the monolithic zirconia needs to be verified in future studies.

Many studies reported that the major disadvantage of Y-TZP is its reduced stability against low temperature degradation (LTD) [36-40]. LTD is defined as the spontaneous tetragonal to monoclinic transformation occurring over time at low temperatures, when the transformation is not triggered by the local stress produced at the tip of the advancing crack [6]. Under hydrothermal changes, an undesired phase transformation from tetragonal phase to the weaker monoclinic zirconia can occur on the surface of the monolithic zirconia FDPs. This is combined with an increase in the surface roughness [39] resulting possibly in high 
abrasion of the antagonist enamel. Future studies should clarify whether wear rate is associated with grain pull out due to LTD.

In this study, the tested specimens were repeatedly used and longitudinal data were therefore available. Consequently, the measurements from one particular specimen were correlated with one another. Thus, linear mixed models with random intercept were applied to investigate the influence of different wear times. Linear mixed models allow for correlated responses by including random effects in the linear predictor.

Heintze [29] compared the ACTA, Zurich, Alabama, MTS and OHSU wear simulation devices for direct resin composites. The wear of ten direct resin composites with the five wear simulations methods showed no comparable results; as all methods follow different wear testing concepts. For characterizing the complex oral wear situation, clinical tests are essential. However, in vitro studies for wear measurement show only little correlation with clinical data [29] but present a comparative evaluation of different materials under standardized conditions [18]. Since no clinical study looked at wear rate of enamel against zirconia with and without veneering ceramic. The results of this study with the monolithic zirconia and their corresponding enamel antagonists require clinical verification. 


\section{Conclusions}

Within the limitations of this study, the following conclusions can be drawn:

1. Polished monolithic zirconia showed the lowest wear rate on enamel antagonists of all tested groups.

2. Glazed zirconia showed higher material wear rate than those of polished monolithic zirconia or monolithic alloy surface due to the abrasion of the glaze layer.

3. Polished zirconia surface showed similar wear rate compared to monolithic alloy.

4. Sandblasted, glazed zirconia using glaze ceramic showed the highest wear of enamel antagonists due to the rough zirconia surface after wear of the glaze layer.

5. While in the groups of monolithic alloy, veneered and both glazed zirconia groups $50 \%$ of the specimens developed cracks in enamel, it was $100 \%$ in both monolithic zirconia groups. 


\section{Acknowledgements:}

The authors are grateful to Mrs Jacqueline Hofmann, Center of Dental Medicine, University of Zurich, for performing the scanning electron microscopy. Special thanks go to Wieland Dental + Technik, Pforzheim, Germany for support this study.

Declaration of interest: The authors report no conflicts of interest. The authors alone are responsible for the content and writing of this paper. 


\section{References}

1. Sturzenegger B, Fehér A, Lüthy H, Schumacher M, Loeffel O, Filser F, Kocher P, Gauckler L, Schärer P. Reliability and strength of all-ceramic dental restorations fabricated by direct ceramic machining (DCM). Int J Comp Dent 2001;4:89-106.

2. Fischer J, Stawarczyk B. Compatibility of machined Ce-TZP/Al2O3 nanocomposite and a veneering ceramic. Dent Mater 2007;23:1500-1505.

3. Aboushelib MN, Kleverlaan CJ. Feilzer AJ. Evaluation of high fracture toughness composite ceramic dental applications. J Prosthodont 2008;17:538-544.

4. Kim HT, Han JS, Yang JH, Lee JB, Kim SH. The effect of low temperature aging on the mechanical property \& phase stability of Y-TZP ceramics. J Adv Prosthodont 2009;1:113-117.

5. Kisi EH, Howard CJ. Crystal structure of zirconia phases and their inter-relation. Key Eng Mater 1998;153:1-36.

6. Lughi V, Sergo V. Low temperature degradation - aging - of zirconia: A critical review of the relevant aspects in dentistry. Dent Mater 2010:807-820.

7. Piconi C, Burger W, Richter HG, Cittadini A, Maccauro G, Covacci V, Bruzzese N, Ricci GA, Marmo E. Y-TZP for artificial join replacements. Biomaterials $1998 ; 19: 1489-1494$.

8. Chevalier J, Deville S, Munch E, Jullian R, Lair F. Critical effect of cubic phase on aging in $3 \mathrm{~mol} \%$ yttria-stabilized zirconia ceramics for hip replacement prothesis. Biomaterials 2004;25:5539-5545.

9. Deville S, Gremillard L, Chevalier J, Fantozzi G. A critical comparisan of methods for the determination of the aging sensitivity in biomedical grade yttria-stabilized zirconia. J Biomed Mater Res B: Appl Biomater 2005;72:239-245. 
10. Ban S, Sato H, Suehiro Y, Nakahishi H, Nawa M. Biaxial flexure strength and low temperature degradation od Ce-TZP/A12O3 nanocomposite and Y-TZP as dental restoratives. J Biomed Mater Res B: Appl Biomater 2008;87B:492-298.

11. Vult von Steyern PV, Carlson P, Nilner K. All-ceramic fixed partial dentures designed according to the DC-Zircon technique. A 2-year clinical study. J Oral Rehabil $2005 ; 32: 180-187$.

12. Raigrodski AJ, Chiche GJ, Potiket N, Hochstedler JL, Mohamed SE, Billiot S, Mercante DE. The efficacy of posterior three-unit zirconium-oxide-based ceramic fixed partial dental prostheses: a prospective clinical pilot study. J Prosthet Dent 2006;96:237-244.

13. Sailer I, Fehér A, Filser F, Gauckler LJ, Lüthy H, Hämmerle CH. Five-Year clinical results of zirconia frameworks for posterior fixed partial dentures. Int J Prosthodont 2007;20: 383-388.

14. Edelhoff D, Florian B, Florian W, Johnen C. HIP zirconia fixed partial denturesclinical results after 3 years of clinical service. Quintessence Int 2008;39:459-471.

15. Schmitt J, Holst S, Wichmann M, Reich S, Gollner M, Hamel J. Zirconia posterior fixed partial dentures: a prospective clinical 3-year follow-up. Int J Prosthodont 2009:22:597-603.

16. Heintze SD, Cavalleri A, Forjanic M, Zellweger G, Rousson V. Wear of ceramic and antagonist - a systematic evaluation of influencing factors in-vitro. Dent Mater $2008 ; 24: 433-449$.

17. Albashaireh ZS, Ghazel M, Kern M. Two-body wear of different ceramic materials opposed to zirconia ceramic. J Prosthet Dent 2010;104:105-113.

18. Preis V, Behr M, Kolbeck C, Hahnel S, Handel G, Rosentritt M. Wear performance of substructure ceramics and veneering porcelains. Denta Mater 2011 [epub aheat] 
19. ISO/TS 14569-2:2001 Dental materials - Guidance on testing of wear - Part 2: Wear by two/ or three body contact.

20. Johansson A, Haraldson T, Omar R, Kiliaridis S, Carlsson GE. An investigation of some factors associated with occlusal tooth wear in a selected high-wear sample. Eur J Oral Sci 1993;101:407-415.

21. Johansson A, Kiliaridis S, Haraldson T, Omar R, Calsson GE. Covariation of some factors associated with occlusal tooth wear in a selected high-wear sample. Eur J Oral Sci 1993;101:398-406.

22. Mair LH, Stolarski TA, VowlesRW, Lloyd CH. Wear: mechanisms, manifestations and measurements. A report of a Workshop. J Dent 1996;24:141-148.

23. Kim SK, Kim KN, Chang IT, Heo SJ. A study of the effect of chewing patterns on occlusal wear. J Oral Rehabil 2001;28:1048-1055.

24. Etman MK. Confocal examination of subsurface cracking in ceramic materials. J Prosthod 2009; 18:550-559.

25. Suputtamongkol K, Anusavice KJ, Suchatlampong C, Sithiamnuai P, Tulapornchai C. Clinical performance and wear characteristics of veneered lithia-disilicate-based ceramic crowns. Dent Mater 2008;24:667-673.

26. Valenti M, Valenti A. Retrospective survival analysis of 261 lithium disilicate crowns in a private general practice. Quintessence Int 2009;40:573-579.

27. Wolfart S, Eschbach S, Scherrer S, Kern M. Clinical outcome of three-unit lithiumdisilicate glas-ceramic fixed dental prostheses: Up to 8 years results. Dent Mater 2009;25:e63-e71.

28. Fasbinder DJ, Dennison JB, Heys D, Neiva G. A clinical evaluation of chairside lithium disilicate CAD/CAM crowns. A two-year report. J Am Dent Assoc 2010;141:10s-14s. 
29. Heintze SD. How to quality validate wear simulation devices methods. Dent Mater $2006 ; 22: 712-734$

30. Rosentritt M, Behr M, Gebhard R, Handel G. Influence of stress simulation parameters on the flexural strength of all-ceramic fixed-partial dentures. Dent Mater $2006 ; 22: 176-182$

31. Rosentritt M, Behr M, von der Zel JM, Feilzer AJ. Approach for valuating the influence of laboratory simulation. Dent Mater 2009;25:348-352.

32. Rosentritt M, Siavikis G, Behr M, Kolbeck C, Handel G. Approach for valuating the significance of laboratory simulation. J Dent 2008;36:1048-1053.

33. Hahnel S, Behr M, Handel G, Rosentritt M. Two-body wear of artificial acrylic and composite resin teeth in relation to antagonist material. J Prosthet Dent 2009;101:269278.

34. Stawarczyk B, Özcan M, Hallmann L, Ender A, Mehl A, Hämmerle CHF. Effect of zirconia sintering temperature on optical and mechanical properties of Y-TZP ceramics. Clin Oral Invest 2011; submitted

35. Chevalier J, Olagnon C, Fantozzi G. Subcritical crack propagation in 3Y-TZP ceramics: static and cyclic fatique. J Am Ceram Soc 1999:82:3129-3138.

36. Al-Amleh B, Lyons K, Swain M. Clinical trials in zirconia: a systematic review. J Oral Rehabil 2010;37:641-652.

37. Tsukuma K, Kubota Y, Tsukidate T. Thermal and mechanical properties of Y2O3stabilized tetragonal zirconia polycrystals. In: Clausen N, Ruehle M, Heuer AH, editors. Science and technology of zirconia II. Columbus, OH: The American Ceramic Society 1984. p. 382-390.

38. Watanabe M, Ilio S, Fukuura I. Aging behavior of Y-TZP. In: Claussen N, Ruehle M, Heuer AH, editors. Science and technology of zirconia II. The American Ceramic Society: Columbus, OH; 1984. p. 391-398 
39. Lange FF, Dunlpo GL, Davis BI. Degradation during ageing of transformation toughened $\mathrm{ZrO} 2-\mathrm{Y} 2 \mathrm{O} 3$ materials at $250^{\circ} \mathrm{C}$. J Am Ceram Soc 1986;69:237-240.

40. Chevalier J. Low-temperature aging of Y-TZP ceramic. J Am Ceram Soc $1999 ; 82: 2150-2154$. 
Tables and figure legends

Table I. The test groups, abbreviations, brands, batch numbers and manufacturers of the tested materials.

Table II. Firing procedures for the ceramics.

Table III. Mean (SD), minimum, maximum, 95\% confidence intervals (95\% CI) of wear of tested reconstruction materials and their enamel antagonists $(\mu \mathrm{m})$. Note: $\mathrm{MC} 1=$ after 120.000 masticatory cycles, MC2 = after 240.000 masticatory cycles, MC3 = after 640.000 masticatory cycles, MC4 = after 1.200.000 masticatory cycles.

Table IV. Estimates of regression coefficients for wear of reconstruction materials (linear mixed models analysis).

Table V. Estimates of regression coefficients for wear of the enamel antagonists (linear mixed models analysis).

Figure 1. Linear mixed models diagram of reconstruction materials wear.

Figure 2. Linear mixed models diagram of enamel antagonists wear.

Figure 3. SEM pictures of abraded reconstruction materials after different masticatory cycles $(\mathrm{MC})$

Figure 4. SEM pictures of abraded enamel antagonists after different masticatory cycles (MC). 
Table I. The test groups, abbreviations, brands, batch numbers and manufacturers of the tested materials.

\begin{tabular}{|c|c|c|c|c|}
\hline Test group & abbreviation & brand & $\begin{array}{l}\text { batch } \\
\text { number }\end{array}$ & manufacturer \\
\hline monolithic alloy & MA & DentaNEM & Z094348 & $\begin{array}{l}\text { Wieland Dental }+ \\
\text { Technik, Pforzheim, } \\
\text { Germany }\end{array}$ \\
\hline veneered zirconia & $\mathrm{VZ}$ & $\begin{array}{l}\text { ZENOTEC Zr } \\
\text { Bridge } \\
\text { transluzent } \\
\text { Liner A3 } \\
\text { Zirox Dentin A3 } \\
\text { Zirox Emanel } 3 \\
\text { Carving Liquid } \\
\text { Standard } \\
\text { Zirox Gaze } \\
\text { X Stain Liquid }\end{array}$ & $\begin{array}{l}405648 \\
1 / 05 \\
1 / 05 \\
1 / 05 \\
30 / 06 \\
02 / 09 \\
10 / 05 \\
\end{array}$ & $\begin{array}{l}\text { Wieland Dental }+ \\
\text { Technik, Pforzheim, } \\
\text { Germany }\end{array}$ \\
\hline $\begin{array}{l}\text { glazed zirconia with } \\
\text { a glaze ceramic }\end{array}$ & GZC & $\begin{array}{l}\text { ZENOTEC Zr } \\
\text { Bridge } \\
\text { transluzent } \\
\text { Zirox Glaze } \\
\text { Stain Liquid }\end{array}$ & $\begin{array}{l}405648 \\
02 / 09 \\
10 / 05\end{array}$ & $\begin{array}{l}\text { Wieland Dental }+ \\
\text { Technik, Pforzheim, } \\
\text { Germany }\end{array}$ \\
\hline $\begin{array}{l}\text { glazed zirconia with } \\
\text { a glaze spray }\end{array}$ & GZS & $\begin{array}{l}\text { ZENOTEC Zr } \\
\text { Bridge } \\
\text { transluzent } \\
\text { Glaze Spray } \\
\text { Zenostar Magic } \\
\text { Glaze }\end{array}$ & $\begin{array}{l}405648 \\
1 / 09\end{array}$ & $\begin{array}{l}\text { Wieland Dental }+ \\
\text { Technik, Pforzheim, } \\
\text { Germany }\end{array}$ \\
\hline $\begin{array}{l}\text { manually polished } \\
\text { monolithic zirconia }\end{array}$ & MAZ & $\begin{array}{l}\text { ZENOTEC Zr } \\
\text { Bridge } \\
\text { transluzent }\end{array}$ & 405648 & $\begin{array}{l}\text { Wieland Dental + } \\
\text { Technik, Pforzheim, } \\
\text { Germany }\end{array}$ \\
\hline $\begin{array}{l}\text { mechanically } \\
\text { polished monolithic } \\
\text { zirconia }\end{array}$ & MEZ & $\begin{array}{l}\text { ZENOTEC Zr } \\
\text { Bridge } \\
\text { transluzent }\end{array}$ & 405648 & $\begin{array}{l}\text { Wieland Dental + } \\
\text { Technik, Pforzheim, } \\
\text { Germany }\end{array}$ \\
\hline
\end{tabular}


Table II. Firing procedures for the ceramics.

\begin{tabular}{|c|c|c|c|c|c|}
\hline \multirow[b]{2}{*}{$\begin{array}{l}\text { Veneering } \\
\text { ceramic }\end{array}$} & \multicolumn{2}{|l|}{ Pre Drying } & \multirow{2}{*}{$\begin{array}{l}\text { Heating } \\
\text { Rate } \\
\left({ }^{\circ} \mathrm{C} / \mathrm{min}\right)\end{array}$} & \multirow{2}{*}{$\begin{array}{l}\text { Firing } \\
\text { Temperature } \\
\left({ }^{\circ} \mathrm{C}\right)\end{array}$} & \multirow{2}{*}{\begin{tabular}{|l} 
Fusion \\
Time \\
$(\mathrm{min})$ \\
\end{tabular}} \\
\hline & \begin{tabular}{|l} 
Temperature \\
$\left({ }^{\circ} \mathrm{C}\right)$
\end{tabular} & $\begin{array}{l}\text { Time } \\
\text { (min) }\end{array}$ & & & \\
\hline Zirox Liner & 575 & 8 & 45 & 930 & 1 \\
\hline Zirox Dentin & 575 & 9 & 45 & 900 & 2 \\
\hline Zirox Enamel & 575 & 8 & 45 & 890 & 1 \\
\hline Zirox Glaze & 575 & 5 & 45 & 880 & 1 \\
\hline Glaze Spray & 575 & 2 & 45 & 880 & 1 \\
\hline
\end{tabular}


Table III. Mean (SD), minimum, maximum, 95\% confidence intervals (95\% CI) of wear of tested reconstruction materials and their enamel antagonists $(\mu \mathrm{m})$. Note: $\mathrm{MC} 1=$ after 120.000 masticatory cycles, MC2 $=$ after 240.000 masticatory cycles, MC3 $=$ after 640.000 masticatory cycles, MC4 = after 1.200.000 masticatory cycles.

\begin{tabular}{|c|c|c|c|c|c|c|c|c|c|}
\hline \multirow{2}{*}{$\begin{array}{l}\text { Test } \\
\text { group } \\
\text { S }\end{array}$} & \multirow{2}{*}{$\begin{array}{l}\text { Masti } \\
\text { catory } \\
\text { cycles }\end{array}$} & \multicolumn{4}{|c|}{ Material wear } & \multicolumn{4}{|c|}{ Antagonist enamel wear } \\
\hline & & Mean (SD) & $\begin{array}{l}\mathrm{mi} \\
\mathrm{n}\end{array}$ & $\max$ & $95 \% \mathrm{CI}$ & Mean (SD) & $\min$ & $\max$ & $95 \% \mathrm{CI}$ \\
\hline \multirow[t]{4}{*}{ MA } & $\mathrm{MC1}$ & $2.8(2.9)$ & 0 & 7 & $(0.24 ; 5.9)$ & $16.3(12.3)$ & 4 & 35 & $(3.4 ; 29.3)$ \\
\hline & $\mathrm{MC2}$ & $5.8(2.3)$ & 2 & 8 & $(3.4 ; 8.3)$ & $24(14.1)$ & 12 & 46 & $(9.2 ; 38.8)$ \\
\hline & MC3 & $10.5(6.1)$ & 3 & 19 & $(4.0 ; 17.0)$ & $34.2(17.9)$ & 14 & 56 & $(15.4 ; 53)$ \\
\hline & MC4 & $13.2(8.3)$ & 5 & 27 & $(4.4 ; 22)$ & $55.3(38.5)$ & 20 & 116 & $(14.9 ; 95.7)$ \\
\hline \multirow[t]{4}{*}{$\mathrm{VZ}$} & MC1 & $12.7(7.9)$ & 3 & 24 & $(4.3 ; 21.0)$ & $26.2(7.7)$ & 14 & 34 & $(18.1 ; 34.2)$ \\
\hline & MC2 & $26.5(20.8)$ & 7 & 59 & $(4.6 ; 48.4)$ & $33(7.2)$ & 19 & 39 & $(25.4 ; 40.7)$ \\
\hline & MC3 & $46.5(30.6)$ & 17 & 95 & $(14.3 ; 78.7)$ & $53.3(17.6)$ & 37 & 82 & $(34.8 ; 71.8)$ \\
\hline & MC4 & $66.8(47.5)$ & 21 & 136 & $(16.9 ; 116.8)$ & $73.5(32.8)$ & 49 & 134 & $(39 ; 108)$ \\
\hline \multirow[t]{4}{*}{ GZC } & MC1 & $38.7(18.1)$ & 15 & 68 & $(19.6 ; 57.7)$ & $51.7(20.6)$ & 22 & 74 & $(30 ; 73.3)$ \\
\hline & $\mathrm{MC} 2$ & $47.3(10.9)$ & 37 & 68 & $(35.9 ; 58.8)$ & $80(18.3)$ & 56 & 112 & $(60.7 ; 99.3)$ \\
\hline & MC3 & $47.8(8)$ & 38 & 62 & $(39.4 ; 56.3)$ & $97(26.9)$ & 65 & 145 & $(68.6 ; 125.3)$ \\
\hline & MC4 & $49.5(10.3)$ & 39 & 69 & $(38.7 ; 60.3)$ & $118(30.9)$ & 92 & 179 & $(85.5 ; 150.5)$ \\
\hline \multirow[t]{4}{*}{ GZS } & $\mathrm{MC1}$ & $30.3(10.9)$ & 19 & 48 & $(18.8 ; 41.8)$ & $24.5(8.3)$ & 17 & 39 & $(15.8 ; 33.2)$ \\
\hline & MC2 & $34(9)$ & 21 & 48 & $(24.5 ; 43.5)$ & $31(13.2)$ & 21 & 56 & $(17 ; 45)$ \\
\hline & MC3 & $58(20.2)$ & 39 & 92 & $(36.7 ; 78)$ & $43.3(11.6)$ & 33 & 65 & $(31.1 ; 55.6)$ \\
\hline & MC4 & $91.3(38.6)$ & 49 & 137 & $(50.8 ; 131.9)$ & $62.2(16.6)$ & 46 & 83 & $(44.7 ; 79.6)$ \\
\hline \multirow[t]{4}{*}{ MAZ } & $\mathrm{MC1}$ & $0.3(0.5)$ & 0 & 1 & $(0.2 ; 0.9)$ & $14.3(5.6)$ & 9 & 21 & $(8.4 ; 20.3)$ \\
\hline & $\mathrm{MC2}$ & $0.5(0.5)$ & 0 & 1 & $(0.07 ; 1.1)$ & $17(7.5)$ & 9 & 28 & $(9.1 ; 24.9)$ \\
\hline & MC3 & $0.5(0.5)$ & 0 & 1 & $(0.07 ; 1.1)$ & $19.3(9.3)$ & 9 & 32 & $(9.5 ; 29.2)$ \\
\hline & MC4 & $0.8(0.8)$ & 0 & 2 & $(0.04 ; 1.7)$ & $27.3(15.2)$ & 12 & 53 & $(11.3 ; 43.3)$ \\
\hline \multirow[t]{4}{*}{ MEZ } & MC1 & $0.3(0.5)$ & 0 & 1 & $(0.2 ; 0.9)$ & $14.7(10.1)$ & 7 & 33 & $(4 ; 25.3)$ \\
\hline & $\mathrm{MC} 2$ & $0.8(0.8)$ & 0 & 2 & $(0.04 ; 1.7)$ & $17(9.8)$ & 8 & 33 & $(6.7 ; 27.3)$ \\
\hline & MC3 & $0.8(0.8)$ & 0 & 2 & $(0.04 ; 1.7)$ & $22(13)$ & 13 & 44 & $(8.3 ; 35.7)$ \\
\hline & MC4 & $0.8(0.8)$ & 0 & 2 & $(0.04 ; 1.7)$ & $28(11.1)$ & 15 & 45 & $(16.3 ; 39.7)$ \\
\hline
\end{tabular}


Table IV. Estimates of regression coefficients for wear of reconstruction materials (linear mixed models analysis).

\begin{tabular}{|l|l|l|l|}
\hline Parameter & Estimate (standard error) & p-values & Significance \\
\hline Constant term & $3.0(6)$ & 0.617 & $(-9.0 ; 15.1)$ \\
\hline MA & $0(0)$ & - & - \\
\hline VZ & $8.6(8.5)$ & 0.314 & $(-8.3 ; 25.7)$ \\
\hline GZC & $38.8(8.5)$ & $<\mathbf{0 . 0 0 1}$ & $(21.7 ; 55.8)$ \\
\hline GZS & $18.5(8.5)$ & $\mathbf{0 . 0 3 3}$ & $(1.5 ; 35.6)$ \\
\hline MAZ & $-2.7(8.5)$ & 0.751 & $(-19.7 ; 14.4)$ \\
\hline MEZ & $-2.5(8.5)$ & 0.771 & $(-19.4 ; 14.6)$ \\
\hline Masticatory cycles (MC) & $9.1 \mathrm{E}-6(5.8 \mathrm{E}-6)$ & 0.119 & $(-2.3 \mathrm{E}-6 ; 2.1 \mathrm{E}-5)$ \\
\hline MA * MC & $0(0)$ & - & $(-2.4 \mathrm{E}-5 ; 7.6 \mathrm{E}-6)$ \\
\hline VZ * MC & $3.9 \mathrm{E}-5(8.2 \mathrm{E}-6)$ & $<\mathbf{0 . 0 0 1}$ & $(-2.5 \mathrm{E}-5 ; 7.5 \mathrm{E}-6)$ \\
\hline GZC * MC & $-1.8 \mathrm{E}-6(8.2 \mathrm{E}-6)$ & 0.824 & $(-1.8 \mathrm{E}-5 ; 1.5 \mathrm{E}-5)$ \\
\hline GZS * MC & $4.8 \mathrm{E}-5(8.2 \mathrm{E}-6)$ & $<\mathbf{0 . 0 0 1}$ & $(3.2 \mathrm{E}-5 ; 6.5 \mathrm{E}-5)$ \\
\hline MAZ * MC & $-8.7 \mathrm{E}-6(8.2 \mathrm{E}-6)$ & 0.290 & \\
\hline
\end{tabular}


Table V. Estimates of regression coefficients for wear of enamel antagonists (linear mixed models analysis).

\begin{tabular}{|l|l|l|l|}
\hline Parameter & Estimate (standard error) & p-values & Significance \\
\hline Constant term & $13.4(6.9)$ & 0.061 & $(-0.6 ; 27.4)$ \\
\hline MA & $0(0)$ & - & - \\
\hline VZ & $8.9(9.8)$ & 0.369 & $(-10.8 ; 28.7)$ \\
\hline GZC & $43.3(9.8)$ & $<\mathbf{0 . 0 0 1}$ & $(23.5 ; 63.2)$ \\
\hline GZS & $8.1(9.8)$ & 0.414 & $(-11.6 ; 27.9)$ \\
\hline MAZ & $-0.1(9.8)$ & 0.990 & $(-19.9 ; 19.7)$ \\
\hline MEZ & $0.4(9.8)$ & 0.972 & $(-19.4 ; 20.2)$ \\
\hline Masticatory cycles (MC) & $3.4 \mathrm{E}-5(5 \mathrm{E}-6)$ & $<\mathbf{0 . 0 0 1}$ & $(2.4 \mathrm{E}-5 ; 4.5 \mathrm{E}-5)$ \\
\hline MA * MC & $0(0)$ & - & $(-3.7 \mathrm{E}-5 ;-9.2 \mathrm{E}-6)$ \\
\hline VZ * MC & $9.2 \mathrm{E}-6(7.1 \mathrm{E}-6)$ & 0.193 & $(-3.6 \mathrm{E}-5 ;-8.4 \mathrm{E}-6)$ \\
\hline GZC * MC & $2.0 \mathrm{E}-5(7.1 \mathrm{E}-6)$ & $\mathbf{0 . 0 0 7}$ & $(5.5 \mathrm{E}-6 ; 3.4 \mathrm{E}-5)$ \\
\hline GZS * MC & $-5.4 \mathrm{E}-7(7.1 \mathrm{E}-6)$ & 0.939 & $(-1.4 \mathrm{E}-5 ; 1.4 \mathrm{E}-5)$ \\
\hline MAZ * MC & $-2.3 \mathrm{E}-5(7.1 \mathrm{E}-6)$ & $\mathbf{0 . 0 0 1}$ & \\
\hline & $-2.2 \mathrm{E}-5(7.1 \mathrm{E}-6)$ & & \\
\hline & & & \\
\hline
\end{tabular}


Figure 1. Linear mixed models diagram of reconstruction materials wear.

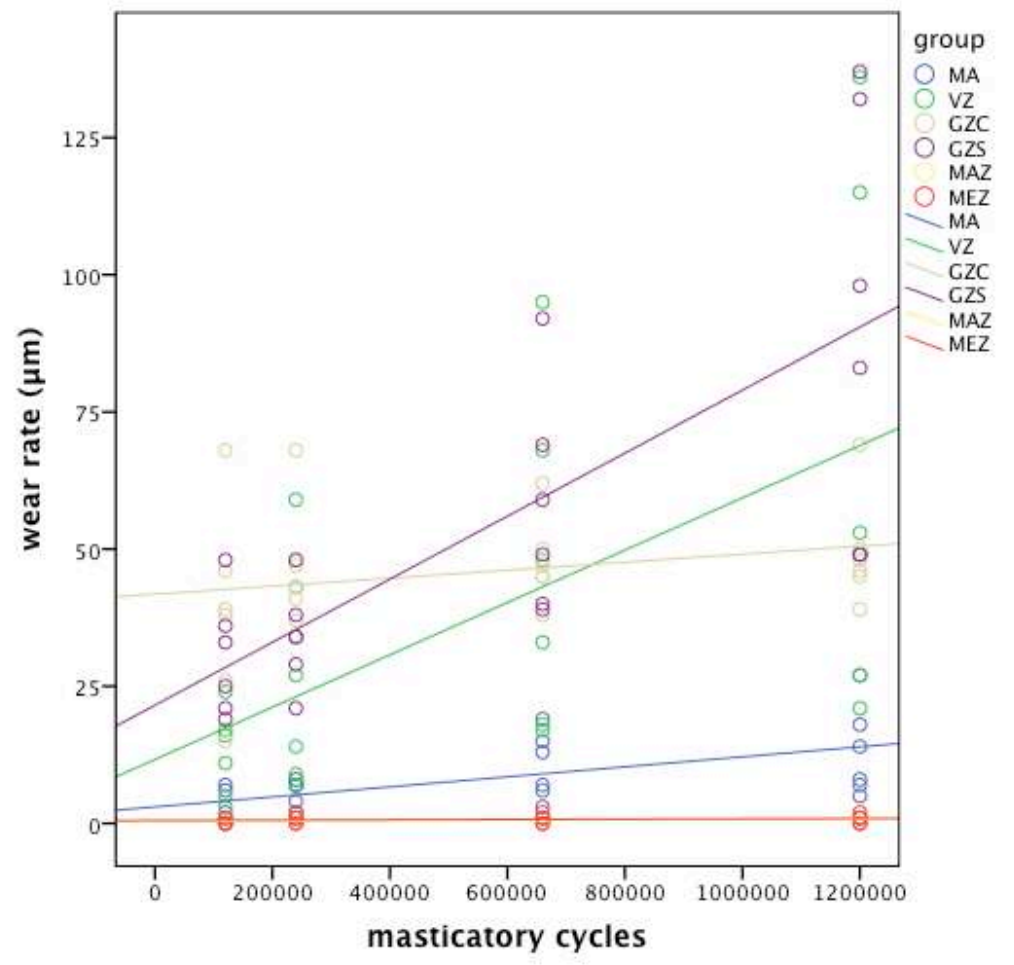


Figure 2. Linear mixed models diagram of enamel antagonists wear.

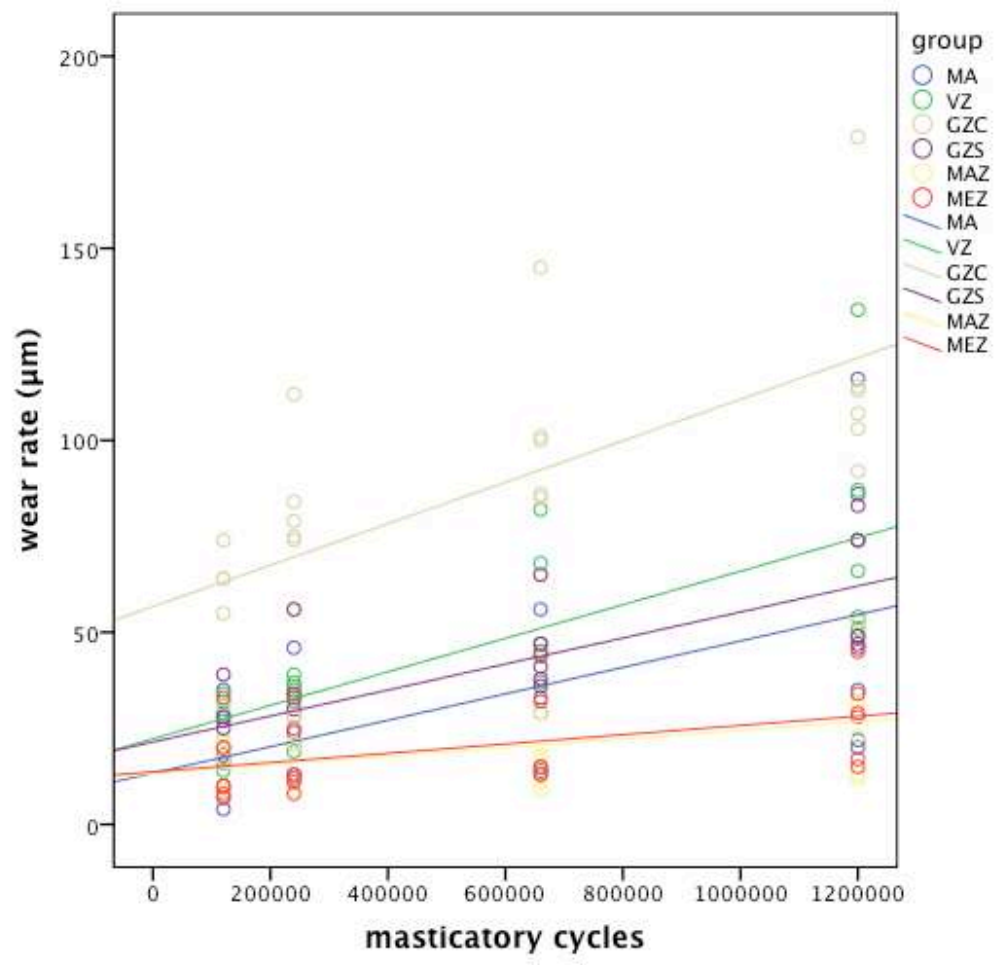


Figure 3. SEM images of the abraded reconstruction materials after different masticatory cycles (MC). Note that the control group (MA) showed little deformation of alloy on the contact surface; the veneered and glazed groups VZ, GZC and GZS presented the highest wear and MAZ and MEZ showed practically no wear.

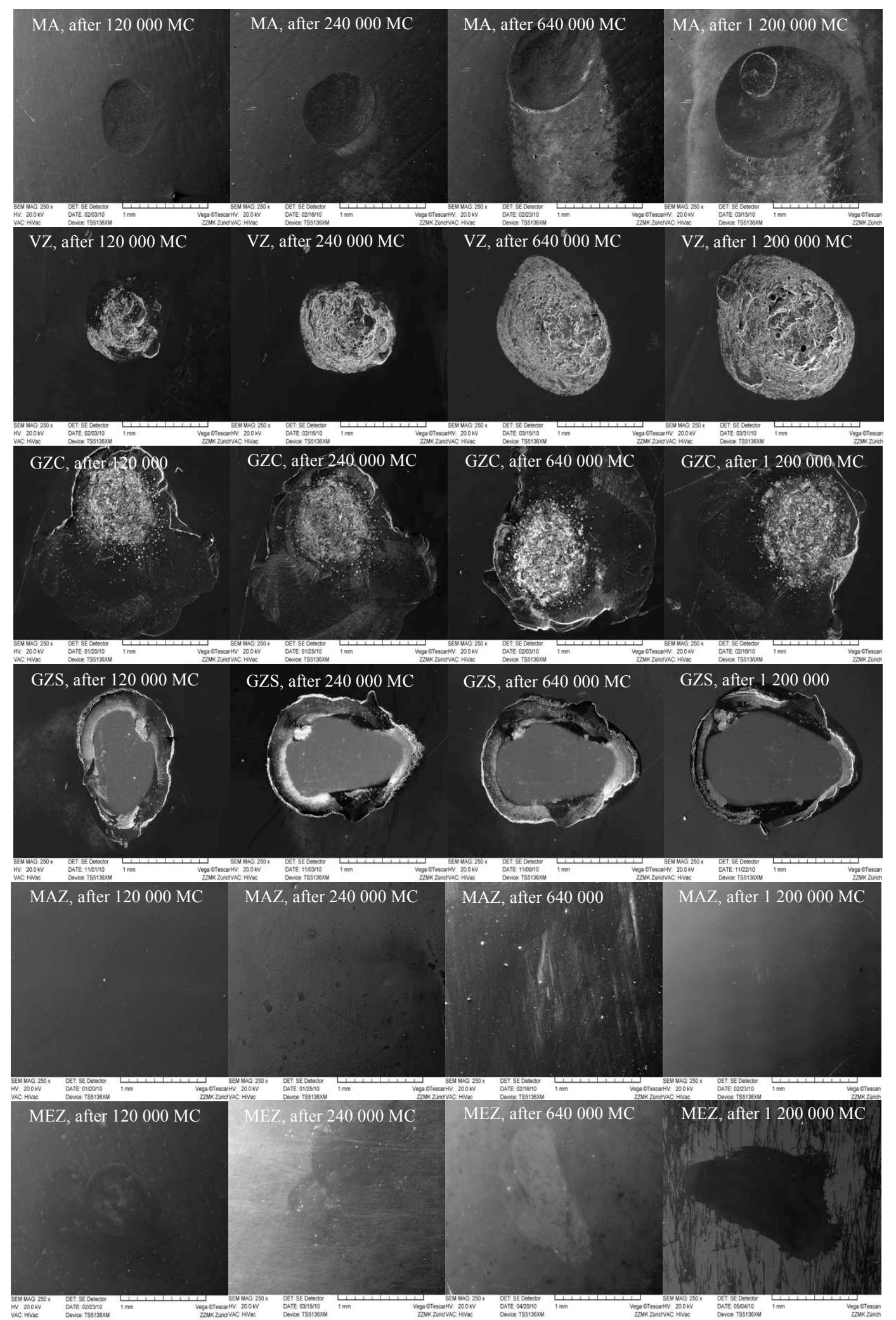


Figure 4. SEM images of the abraded enamel antagonists after different masticatory cycles (MC). Note that VZ, GZC and GZS showed the highest wear in enamel. The group images of VZ, GZS and MAZ indicates crack formation in enamel.

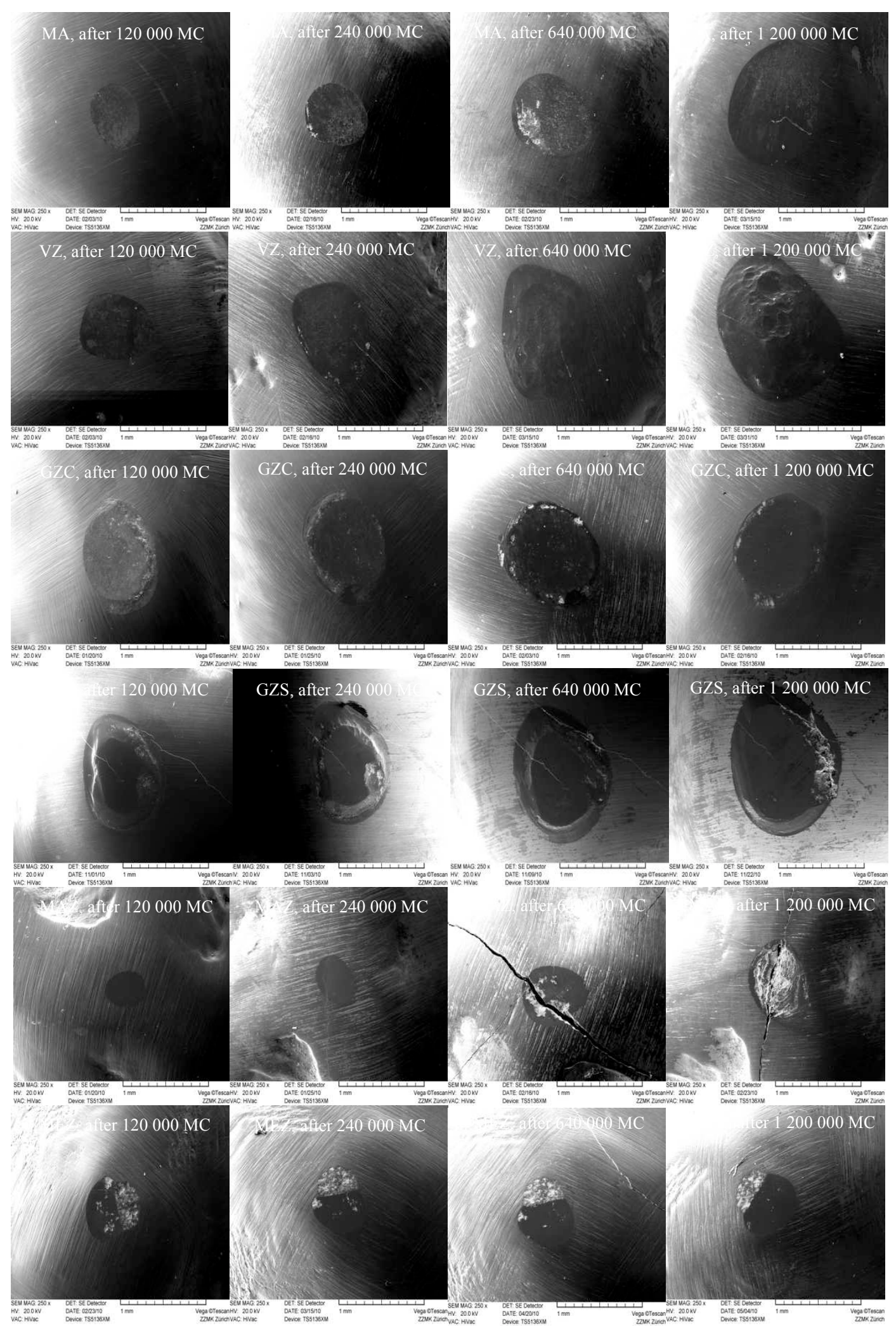

